\title{
DEVELOPMENT OF THERMOREGULATION IN HAWAIIAN BROWN NODDIES (ANOUS STOLIDUS PILEATUS)
}

\author{
P. Mbaabu Mathiu, ${ }^{1 *}$ William R. Dawson ${ }^{2} \dagger$ and G. Causey Whitrow ${ }^{1}$ \\ ${ }^{1}$ Department of Physiology, John A. Burns School of Medicine, University of Hawaii, 1960 East-West \\ Road, Honolulu, HI 96822 and ${ }^{2}$ Museum of Zoology and Department of Biology, University of Michigan, \\ Ann Arbor, MI 48109, U.S.A.
}

(Received 13 May 1991; accepted 8 August 1991)

\begin{abstract}
Oxygen consumption $\left(\dot{V} \mathrm{O}_{2}\right)$ and body temperature $\left(T_{\mathrm{b}}\right)$ of Hawaiian brown noddies (Anous stolidus pileatus [Aves: Laridae]) during late incubation and in the first $24 \mathrm{~h}$ after hatching were measured at ambient temperatures $\left(T_{a}\right)$ between 28 and $38^{\circ} \mathrm{C}$ and between 15 and $43^{\circ} \mathrm{C}$, respectively. Evaporative cooling by hatchings at $T_{\mathrm{a}}$ of $36-43^{\circ} \mathrm{C}$ was also measured.

2. Throughout the late incubation stages studied, $\dot{V} \mathrm{O}_{2}$ and $T_{\mathrm{b}}$ both varied directly with $T_{\mathrm{a}}$ in an ectothermic pattern.

3. The hatchlings successfully regulated $T_{\mathrm{b}}$ at $T_{\mathrm{a}}$ between ca. 29 and $43^{\circ} \mathrm{C}$.

4. The functional basis of the abrupt increase in thermoregulatory capacity with hatching is discussed.
\end{abstract}

Key Word Index: Anous stolidus pileatus; bird; late incubation embryos; pipping; hatchlings; metabolic level; development of homeothermy; regulatory thermogenesis; evaporative cooling

\section{INTRODUCTION}

Studies have been conducted on a broad assortment of birds concerning post-hatching events involved in the full establishment of homeothermy (see Dawson and Hudson, 1970). Restriction of observations to the period starting with emergence of chicks from the egg does not appear to handicap seriously the analysis in the case of altricial species. However, it could obscure important steps in precocial and semi-precocial forms, for their chicks may hatch with significant thermoregulatory capacities (e.g. Dawson, 1984). This circumstance requires at a minimum that observations on the physiological responses of these young birds to external temperature be initiated during the late stages of incubation. We report here on our effort to do this for the semi-precocial Hawaiian brown noddy (Anous stolidus pileatus [Aves: Laridae]), which we studied from just before the initiation of pipping through the first $24 \mathrm{~h}$ after hatching. The pipping process extends over approx. 5 days in this species (Pettit and Whittow, 1983), a sufficient interval to allow determination of whether the improved access to oxygen associated with internal pipping and the establishment of a pip hole in the shell produces any enhancement of capacities for regulatory thermogenesis prior to hatching.

*Present address: Department of Animal Physiology at Chiromo, Riverside Drive, University of Nairobi, P.O. Box 30197, Nairobi, Kenya.

†All correspondence should be addressed to: William $\mathbf{R}$. Dawson, Museum of Zoology, University of Michigan, Ann Arbor, MI 48109-1079, U.S.A. [Tel: (313) 764-0476].

\section{MATERIALS AND METHODS}

\section{Experimental subjects}

Eggs representing late incubation unpipped, externally pipped (star fractured), internally pipped, and pip-holed stages were collected in a nesting colony of brown noddies on Manana Island, Oahu, Hawaii $\left(21^{\circ} 20^{\prime} \mathrm{N}, 157^{\circ} 40^{\prime} \mathrm{W}\right)$. The eggs were packed in plastic boxes padded with cotton wool to maintain them near incubation temperature during transport to the laboratory. This transfer was by boat and automobile, with the journey requiring approx. $1 \mathrm{~h}$. Following arrival in the laboratory the eggs were classified as to stage. Pip-holed eggs were obvious. Eggs within 1-2 days of pipping and star fractured ones were identified by candling and by a combination of visual and tactile examination, respectively. Vocalizations by the chicks and extensive cracks in the shell indicated internally pipped eggs. Once identified as to stage, all eggs were numbered and placed in an incubator at $36^{\circ} \mathrm{C}$ and $60 \%$ r.h. They were examined and turned several times daily. Time of hatching was recorded and the body mass of the newly emerged chick determined. Following weighing, the bird was marked and returned to the incubator for at least $3 \mathrm{~h}$ to allow its down to dry and become fluffy. No experiments were performed on hatchlings until this had occurred. While in the laboratory, the chicks were fed canned cat food ad libitum.

\section{Physiological measurements}

Oxygen consumption $\left(\dot{V O}_{2}\right)$ of embryos in eggs at the four stages referred to above was determined in 90-min tests at constant ambient temperatures $\left(T_{\mathrm{a}}\right)$ between 28 and $38^{\circ} \mathrm{C}$. Study of hatchlings involved 
2-h tests at constant $T_{\mathrm{a}}$ between 15 and $43^{\circ} \mathrm{C}$. Mass of the egg or hatchling was determined just before placement in a 1-liter plexiglas metabolism chamber. Three of these chambers were used so that concurrent observations could be made on that many eggs or chicks. Following introduction of the experimental subject, each of these chambers was placed in a Hotpack constant temperature cabinet and connected to a separate open circuit metabolism system. This cabinet controlled $T_{\mathrm{a}}$ in the chambers to within $\pm 0.2^{\circ} \mathrm{C}$ of the set value, as verified by thermistors used in conjunction with a Yellow Springs Instruments multichannel Telethermometer (YSI 46-TUC). Dry air from the laboratory's ventilation system was metered through these chambers at rates exceeding $300 \mathrm{ml} / \mathrm{min}$ for hatchlings and $200 \mathrm{ml} / \mathrm{min}$ for embryos. The flow rates for the hatchlings were increased sufficiently at $T_{\mathrm{a}}$ exceeding $36^{\circ} \mathrm{C}$ to maintain the chamber humidity at or below $2 \mathrm{kPa}$. The oxygen contents of dry, $\mathrm{CO}_{2}$ free incurrent and excurrent air were determined with an Ametek Oxygen Analyzer (S-3A/II). Drierite and Ascarite were used as desiccant and $\mathrm{CO}_{2}$ absorbent, respectively. Rate of oxygen consumption (all gas volumes corrected to STPD) over the last $15 \mathrm{~min}$ of the 90-min or 2-h test was calculated with equation (2) of Hill (1972).

Rates of pulmocutaneous evaporation (referred to subsequently as total evaporative water loss, TEWL) by hatchlings were also determined in the final $15 \mathrm{~min}$ of tests at $T_{\mathrm{a}}$ of 36,40 and $43^{\circ} \mathrm{C}$. A shallow container of mineral oil was added to the bottom of each chamber to cover any excrement voided during experiments and prevent it from adding water vapour to the system. The hatchling rested on a wire mesh platform above this container during a test. The TEWL was determined over a precisely timed interval by measuring the increase in mass of an absorbent train containing Drierite. All weighings were made on an analytical balance (Mettler H6). The absorbent train was connected to the outlet port of the metabolism chamber by $6.3-\mathrm{mm}$ copper tubing to prevent any errors from diffusion of water vapour into the system that might have occurred through plastic tubing. In the minute or two after conclusion of the measurements of $\dot{V} \mathrm{O}_{2}$ and TEWL, respiratory frequencies of the hatchlings were also measured at 36 and $40-43^{\circ} \mathrm{C}$. This involved replacing the incurrent and excurrent air connections for the chamber with a nylon tubing connection for a Grass PT-5 pressure transducer. This transducer was coupled with a Grass recording oscillograph (model 5D) via a low level d.c. amplifier (model 5P1H).
Body temperatures $\left(T_{\mathrm{b}}\right)$ of the embryos or hatchlings were determined at the end of metabolism tests, immediately after removal of the egg or chick from the chamber. A small animal probe from the YSI Telethermometer referred to above was inserted into the egg to near its centre. Embryos were sacrificed and dissected before weighing, so that their yolk-free masses could be determined. The hatchlings' body temperatures were determined rectally and the birds then weighed. A few of these birds were also sacrificed for measurement of the mass of their down and/or the masses of their excised leg and breast muscles. However, most were returned to their parents in the nesting colony.

\section{Statistics}

Means for various measurements are presented with their standard deviations. Comparisons of values for $\dot{V} \mathrm{O}_{2}$, TEWL and $T_{\mathrm{b}}$ for the various stages treated in this study were carried out using analysis of variance (ANOVA). Probabilities below 0.05 for $F$ values are considered significant. The independent samples $t$-test was used to determine whether mean $\dot{V} \mathrm{O}_{2}$ for various $T_{\mathrm{a}}$ differed significantly from that for $36^{\circ} \mathrm{C}$. Probabilities of less than 0.05 were regarded as significant. Best fit regression equations and correlation coefficients $(r)$ were determined using the Sigmaplot program (Jandel Scientific).

\section{Eggs}

Relation of oxygen consumption to temperature. The yolk-free mass of the embryos continued to increase over the last stages of incubation, while the total mass of the eggs containing them declined (Table 1). Over the range of $T_{\mathrm{a}}$ studied $\left(28-38^{\circ} \mathrm{C}\right)$, the increase in embryonic mass was accompanied by some changes in mass-specific metabolism. Embryos in late unpipped and in star fractured eggs had similar $(P>0.05)$ mass-specific $\dot{V} \mathrm{O}_{2}$ which were significantly lower $(P<0.05)$ than that for individuals in internally pipped eggs. These latter, in turn, had a significantly lower rate than embryos in pip-holed eggs (Fig. 1; Table 1). No sign of effective regulatory thermogenesis at cooler $T_{\mathrm{a}}$ was detected in any of these embryos at the end of 90-min exposures-mass-specific $\mathrm{VO}_{2}$ varied directly with $T_{\mathrm{a}}$ even in the oldest embryos (in pipped-holed eggs) studied (Fig. 1). The extent of the temperature dependence of this function at the various stages is indicated by comparison of the

Table 1. Egg and yolk-free embryonic masses and oxygen consumption at two ambient temperatures during late

\begin{tabular}{|c|c|c|c|c|c|}
\hline \multirow[b]{2}{*}{ Egg stage } & \multirow{2}{*}{$\begin{array}{c}\text { Egg mass } \\
(\mathrm{g})\end{array}$} & \multirow{2}{*}{$\begin{array}{l}\text { Yolk-free } \\
\text { embryonic mass } \\
\text { (g) }\end{array}$} & \multicolumn{2}{|c|}{$\begin{array}{c}\dot{V} \mathrm{O}_{2} \\
\left(\mathrm{ml} \mathrm{O}_{2}\left[\mathrm{gh}^{-1}\right)\right.\end{array}$} & \multirow{2}{*}{$\begin{array}{l}Q_{10} \\
\text { for } \\
\dot{V} \mathrm{O}_{2}\end{array}$} \\
\hline & & & $28^{\circ} \mathrm{C}$ & $38^{\circ} \mathrm{C}$ & \\
\hline $\begin{array}{l}\text { Late incubation, unpipped } \\
\text { Externally pipped } \\
\text { Internally pipped } \\
\text { Pip-holed }\end{array}$ & $\begin{array}{l}35.14 \pm 1.76(24)^{*} \\
33.86 \pm 2.45(25) \\
33.53 \pm 2.19(25) \\
32.33 \pm 3.26(25)\end{array}$ & $\begin{array}{l}17.09 \pm 2.08(24) \\
18.32 \pm 0.99(25) \\
21.66 \pm 1.23(25) \\
22.53 \pm 2.21(25)\end{array}$ & $\begin{array}{l}0.61 \pm 0.10 \\
0.50 \pm 0.01 \\
0.74 \pm 0.06 \\
0.71 \pm 0.08\end{array}$ & $\begin{array}{l}0.94 \pm 0.12 \\
1.00 \pm 0.06 \\
1.41 \pm 0.20 \\
1.62 \pm 0.16\end{array}$ & $\begin{array}{l}1.65 \\
2.18 \\
2.02 \\
2.28\end{array}$ \\
\hline
\end{tabular}

*The values presented are the mean \pm SD. The numbers in parentheses indicate sample sizes. The measurements on which the values for $\dot{V} \mathrm{O}_{2}$ are based are plotted in Fig. 1 . $Q_{10}$ 's were calculated with $T_{\mathrm{b}}$ determined from the appropriate equation in Table 2. 


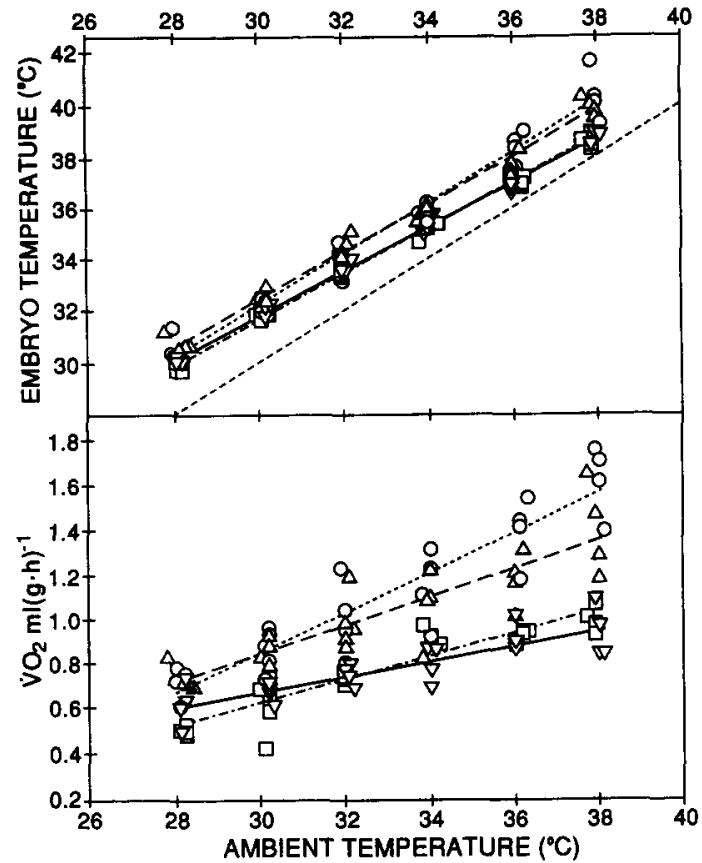

Fig. 1. Oxygen consumption $\left(\dot{V}_{2}\right)$ and body temperature of embryos in unpipped $(\nabla,-)$, externally pipped $(\square,-\cdot-\cdot)$, internally pipped $(\Delta,-\longrightarrow)$ and pip-holed eggs $(0, \ldots)$ of brown noddies at various ambient temperatures. The equations for the respective linear regression lines for the various stages are given in Table 1 (equations 1-8). The lower diagonal line (---) in the top panel links equivalent values of body and ambient temperature.

respective mean values obtained at 38 and $28^{\circ} \mathrm{C}$ (Table 1) and of equations (1), (3), (5) and (7) (Table 2).

Relation of temperature of eggs to ambient temperature. Body temperatures of embryos at the end of metabolic tests conducted between 28 and $38^{\circ} \mathrm{C}$ fell within $3^{\circ} \mathrm{C}$ of $T_{\mathrm{a}}$ (Fig. 1), with the values for embryos in internally pipped and pip-hole eggs tending to be slightly higher than those for ones at the two earlier stages. For example, at $T_{\mathrm{a}}$ near $38^{\circ} \mathrm{C}$, these older

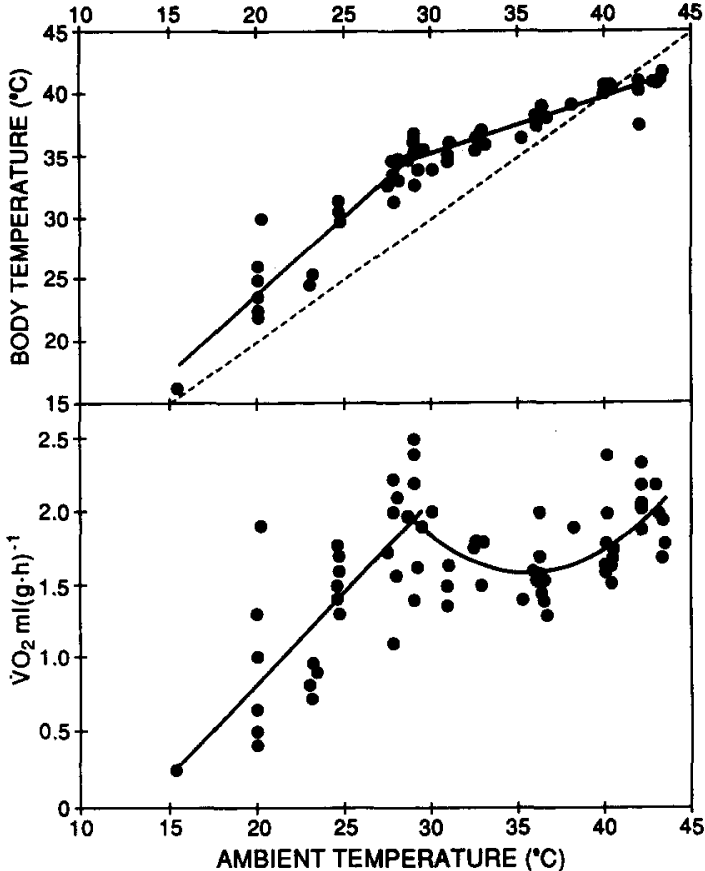

Fig. 2. Oxygen consumption $\left(\mathrm{VO}_{2}\right)$ and body temperature of hatchling brown noddies at different ambient temperatures. Note that $29^{\circ} \mathrm{C}$ represents an important boundary in the thermal dependence of both physiological functions. The regression lines in the two panels are described by equations (9-12) in Table 1. The diagonal line (---) in the upper panel links equivalent values of body and ambient temperature.

embryos were approx. $2^{\circ} \mathrm{C}$ warmer than their surroundings, whereas the differential was less than $1{ }^{\circ} \mathrm{C}$ for noddies in late unpipped and externally pipped eggs. Slightly larger differentials were noted at the cooler $T_{\mathrm{a}}$ at which experiments involving embryos were carried out. This might be due to the eggs not having reached thermal equilibrium by the end of the 90-min tests. Equations (2), (4), (6) and (8) (Table 2) describe the relations of $T_{\mathrm{b}}$ to $T_{\mathrm{a}}$ for embryos at the four stages.

Table 2. Equations for the relations of oxygen consumption, total evaporative water loss, respiratory frequency and body temperature to ambient temperature in embryonic and hatchling brown noddies

\begin{tabular}{|c|c|c|c|c|}
\hline Stage & $\begin{array}{c}T_{\mathrm{a}} \text { range } \\
\left({ }^{\circ} \mathrm{C}\right)\end{array}$ & & Equation* & $\begin{array}{l}\text { Coefficient of } \\
\text { determination } \\
\left(r^{2}\right)\end{array}$ \\
\hline Embryos in late incubation, unpipped eggs & $\begin{array}{l}28-38 \\
28-38\end{array}$ & $\begin{array}{l}\text { (1) } \\
(2)\end{array}$ & $\begin{aligned} \dot{V} O_{2} & =-0.41+0.04 T \\
T_{\mathrm{b}} & =5.86+0.86 T_{\mathrm{a}}\end{aligned}$ & $\begin{array}{l}0.79 \\
0.99\end{array}$ \\
\hline Embryos in externally pipped eggs & $\begin{array}{l}28-38 \\
28-38\end{array}$ & $\begin{array}{l}\text { (3) } \\
\text { (4) }\end{array}$ & $\begin{array}{c}\dot{V} \mathrm{O}_{2}=-0.96+0.05 T_{\mathrm{a}} \\
T_{\mathrm{b}}=5.02+0.89 T\end{array}$ & $\begin{array}{l}0.86 \\
0.99\end{array}$ \\
\hline Embryos in internally pipped eggs & $\begin{array}{l}28-38 \\
28-38\end{array}$ & $\begin{array}{l}(5) \\
(6)\end{array}$ & $\begin{aligned} \dot{V} \mathrm{O}_{2} & =-1.08+0.06 T_{\mathrm{a}} \\
T_{\mathrm{b}} & =4.85+0.92 T_{\mathrm{a}}\end{aligned}$ & $\begin{array}{l}0.74 \\
0.99\end{array}$ \\
\hline Embryos in pip-holed eggs & $\begin{array}{l}28-38 \\
28-38\end{array}$ & $\begin{array}{l}(7) \\
(8)\end{array}$ & $\begin{aligned} \dot{V} \mathrm{O}_{2} & =-1.87+0.09 T_{\mathrm{a}} \\
T_{\mathrm{b}} & =2.17+T_{\mathrm{a}}\end{aligned}$ & $\begin{array}{l}0.85 \\
0.99\end{array}$ \\
\hline Hatchlings & $\begin{array}{l}29-43 \\
29-43 \\
15-29 \\
15-29 \\
36-43 \\
36-43 \\
36-43\end{array}$ & $\begin{array}{l}(9) \\
(10) \\
(11) \\
(12) \\
(13) \\
(14) \\
(15)\end{array}$ & $\begin{aligned} \dot{V} \mathrm{O}_{2} & =12.116-0.593 T_{\mathrm{a}}+0.008\left(T_{\mathrm{a}}\right)^{2} \\
T_{\mathrm{b}} & =18.184+0.648 T_{\mathrm{a}}-0.003\left(T_{\mathrm{a}}\right)^{2} \\
\dot{V} \mathrm{O}_{2} & =-1.66+0.13 T_{\mathrm{a}} \\
T_{\mathrm{b}} & =-1.08+1.25 T_{\mathrm{a}} \\
\mathrm{TEWL} & =344.68-19.84 T_{\mathrm{a}}+0.29\left(T_{\mathrm{a}}\right)^{2} \\
\mathrm{TEWL} / \dot{V} \mathrm{O}_{2} & =161.30-9.35 T_{\mathrm{a}}+0.14\left(T_{\mathrm{a}}\right)^{2} \\
f & =-2709.80+112.91 T_{\mathrm{a}}-1.02\left(T_{\mathrm{a}}\right)^{2}\end{aligned}$ & $\begin{array}{l}0.30 \\
0.86 \\
0.60 \\
0.87 \\
0.95 \\
0.96 \\
0.92\end{array}$ \\
\hline
\end{tabular}

\footnotetext{
* Oxygen consumption $\left(\dot{V} \mathrm{O}_{2}\right)$, total evaporative water loss (TEWL), TEWL/ $\dot{V} \mathrm{O}_{2}$ and respiratory frequency $(f)$ are in ml $\mathrm{O}_{2}(\mathrm{~g} h)^{-1}$,
} $\mathrm{mg} \mathrm{H}_{2} \mathrm{O}(\mathrm{g} \mathrm{h})^{-1}$, $\mathrm{mg} \mathrm{H}_{2} \mathrm{O} / \mathrm{ml} \mathrm{O}_{2}$ and breaths (min) $)^{-1}$, respectively. Body and ambient temperatures $\left(T_{\mathrm{b}}\right.$ and $T_{\mathrm{a}}$, respectively) are in ${ }^{\circ} \mathrm{C}$. 


\section{Hatchlings}

Relation of oxygen consumption to temperature. Mean body mass of hatchings was $23.85 \pm 2.27 \mathrm{~g}$ $(N=71)$. Three features are apparent in the response of their $\dot{V} \mathrm{O}_{2}$ at the end of metabolism experiments to $T_{\mathrm{a}}$ (Fig. 2). First, metabolic rate varied directly with $T_{\mathrm{a}}$ between 36 and $43.2^{\circ} \mathrm{C}$, rising from $1.56 \pm 0.18 \mathrm{ml}$ $\mathrm{O}_{2}(\mathrm{~g} \mathrm{~h})^{-1}$ at the former $T_{\mathrm{a}}$ to $2.02 \pm 0.20 \mathrm{ml} \overline{\mathrm{O}}_{2}(\mathrm{~g} \mathrm{~h})^{-1}$ at the latter. We subsequently refer to the rate at $36^{\circ} \mathrm{C}$ as the "thermoneutral metabolic rate" for the brown noddy. Secondly, $\dot{V} \mathrm{O}_{2}$ varied inversely with temperature between 29 and $36^{\circ} \mathrm{C}$. Over this range $\dot{V} \mathrm{O}_{2}$ increased from $1.56 \mathrm{ml} \mathrm{O}_{2}(\mathrm{~g} \mathrm{~h})^{-1}$ to $2.00 \pm 0.38 \mathrm{ml}$ $\mathrm{O}_{2}(\mathrm{~g} \mathrm{~h})^{-1}$ with declining $T_{\mathrm{a}}$. The temperature dependence of $\dot{V} \mathrm{O}_{2}$ between 29 and $43.2^{\circ} \mathrm{C}$ can be described by a single curvilinear relation (equation (9), Table 2 ). Finally, $\dot{V} \mathrm{O}_{2}$ also varied directly with $T_{\mathrm{a}}$ below $29^{\circ} \mathrm{C}$, falling to $0.24 \mathrm{ml} \mathrm{O}_{2}(\mathrm{~g} \mathrm{~h})^{-1}$ at the end of $2-\mathrm{h}$ tests conducted at $15^{\circ} \mathrm{C}$ (equation (11), Table 2).

Relation of body temperature to ambient tempera. ture. Body temperature of hatchlings at the end of the 2 -h tests varied directly with $T_{\mathrm{a}}$ over the entire range studied $\left(15-43.2^{\circ} \mathrm{C}\right)$. The trend was most pronounced between 15 and ca. $29^{\circ} \mathrm{C}$ (see equation (12), Table 2), a range in which reductions of $T_{\mathrm{a}}$ led to conditions that ultimately impaired or eliminated the hatchlings' capacities for regulatory thermogenesis. Body temperature also varied directly with $T_{\mathrm{a}}$ above $29^{\circ} \mathrm{C}$ (see equation (10), Table 2), but the trend is less pronounced than at lower temperatures. At $36^{\circ} \mathrm{C}$, the $T_{\mathrm{B}}$ used for incubating eggs and brooding chicks, the $T_{\mathrm{b}}$ of the hatchlings averaged $38.1 \pm 0.7^{\circ} \mathrm{C}$. Hatchlings tested at 40 and $43^{\circ} \mathrm{C}$ had $T_{b}$ near 40 and $40.5^{\circ} \mathrm{C}$, respectively.

Morphological and behavioural components of cold defence. Morphological and behavioural observations supplement metabolic measurements in characterizing the rudimentary cold defence of hatchling brown noddies. The down of these birds, which is fine in texture, covers most of the body. In the 5 hatchlings measured it averaged thickest on the dorsum $(10.5 \mathrm{~mm})$, followed by the ventral surface $(9.0 \mathrm{~mm})$, and the crown $(4.0 \mathrm{~mm})$. The mean mass of this down was $0.435 \pm 0.077 \mathrm{~g}$, or $1.7 \pm 0.40 \%$ of the total body mass. On the day of hatching, brown noddies apparently can adjust the insulation provided by this plumage, for they all showed ptiloerection at cooler $T_{\mathrm{a}}\left(\leqslant 33^{\circ} \mathrm{C}\right)$. They also adopted a posture serving to reduce the amount of exposed surface at such $T_{\mathrm{a}}$. These activities should increase the hatchlings' ability to conserve heat, an inference supported by analysis of thermal conductances $(c)$ calculated from data for the last $15 \mathrm{~min}$ of metabolism tests $\left(c=\dot{H}_{\mathrm{m}} /\left[T_{\mathrm{b}}-T_{\mathrm{a}}\right]\right.$, where $\dot{H}_{\mathrm{m}}$ is heat production obtained from measurements of $\dot{V} \mathrm{O}_{2}$ using a caloric equivalent of $20.08 \mathrm{~J} / \mathrm{ml}$ $\mathrm{O}_{2}$ ). The value of $c$ drops from $4.14 \mathrm{~mW}\left(\mathrm{~g}^{\circ} \mathrm{C}\right)^{-1}$ at

Table 3. Masses of leg and breast muscles of brown noddy hatchlings (mean body mass, $25.1 \pm 1.2 \mathrm{~g}^{*}$ )

\begin{tabular}{lccc}
\hline & & \multicolumn{2}{c}{ Tissue mass* } \\
\cline { 3 - 4 } Tissue & $N$ & $(\mathrm{~g})$ & $\begin{array}{c}\text { Per cent of } \\
\text { body mass }\end{array}$ \\
\hline Leg muscles & 10 & $1.50 \pm 0.18 *$ & 5.8 \\
Breast muscles & 11 & $0.57 \pm 0.06$ & 2.28 \\
\hline "Mean \pm SD. & & \multicolumn{3}{l}{}
\end{tabular}

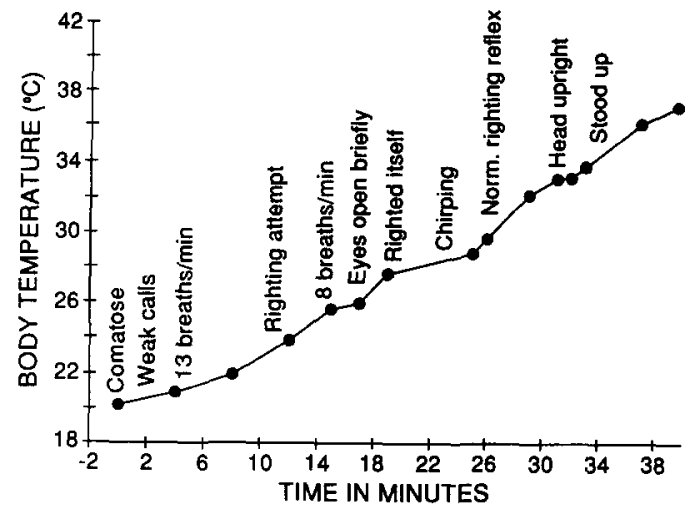

Fig. 3. Body temperature and associated behaviours of a hatchling brown noddy during rewarming from hypothermia under a heat lamp in a room where $T_{\mathrm{a}}$ was $23^{\circ} \mathrm{C}$.

$36^{\circ} \mathrm{C}$ to 2.02 and $1.41 \mathrm{~mW}\left(\mathrm{~g}^{\circ} \mathrm{C}\right)^{-1}$ at 29 and $24.7^{\circ} \mathrm{C}$, respectively. The corresponding surface-specific values are $1.46,0.70$ and $0.51 \mathrm{~mW}\left(\mathrm{~cm}^{2}{ }^{\circ} \mathrm{C}\right)^{-1}$, respectively (surface area for the hatchlings was estimated with Walsberg and King's, 1978, equation $A=8.11 \mathrm{~m}^{0.67}$, where $A$ is in $\mathrm{cm}^{2}$ and $m$ is body mass in $\mathrm{g}$ ). The drop in $c$ between 29 and $24.7^{\circ} \mathrm{C}$ may reflect in part changes in tissue perfusion and ventilation resulting from the hypothermia evident at the lower $T_{\mathrm{a}}$.

Shivering was consistently noted at $29^{\circ} \mathrm{C}$ and it persisted to somewhat lower $T_{\mathrm{a}}$. The leg musculature should be prominent in this activity, for its mass substantially exceeds that of the breast muscles (Table 3). Hatchlings became comatose when cold exposure resulted in $T_{\mathrm{b}}$ lower than ca $20^{\circ} \mathrm{C}$. One was forced into hypothermia by placing it in a freezer until its $T_{\mathrm{b}}$ fell to $20^{\circ} \mathrm{C}$. It was then rewarmed by exposing it to an infrared lamp in a room where $T_{\mathrm{a}}$ was $23^{\circ} \mathrm{C}$. This hatchling was comatose when its $T_{\mathrm{b}}$ was $20.2^{\circ} \mathrm{C}$, but it could right itself at $27.7^{\circ} \mathrm{C}$ (Fig. 3). Tremors indicative of shivering were not observed during the recovery.

Heat defence. Brown noddy hatchlings responded to warm $T_{\mathrm{a}}$ by increasing respiratory frequency (Fig. 4; equation (15), Table 2). Mean values observed at 36 , 40 and $43^{\circ} \mathrm{C}$ were $40 \pm 9(N=8), 171 \pm 24(N=5$, and $252 \pm 52(N=5)$ breaths/min, respectively. The increased respiratory activity at the higher $T_{\mathrm{a}}$ was accompanied by behavioural changes. The hatchlings

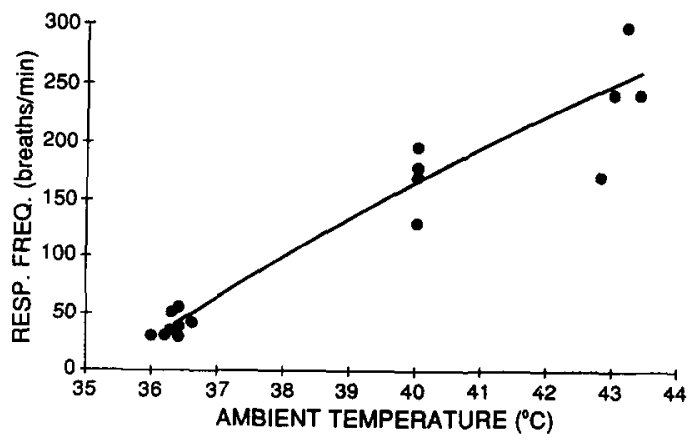

Fig. 4. Respiratory frequency of hatchling brown noddies at different ambient temperatures. The solid line fitted to the data represents equation (15) (Table 1). 


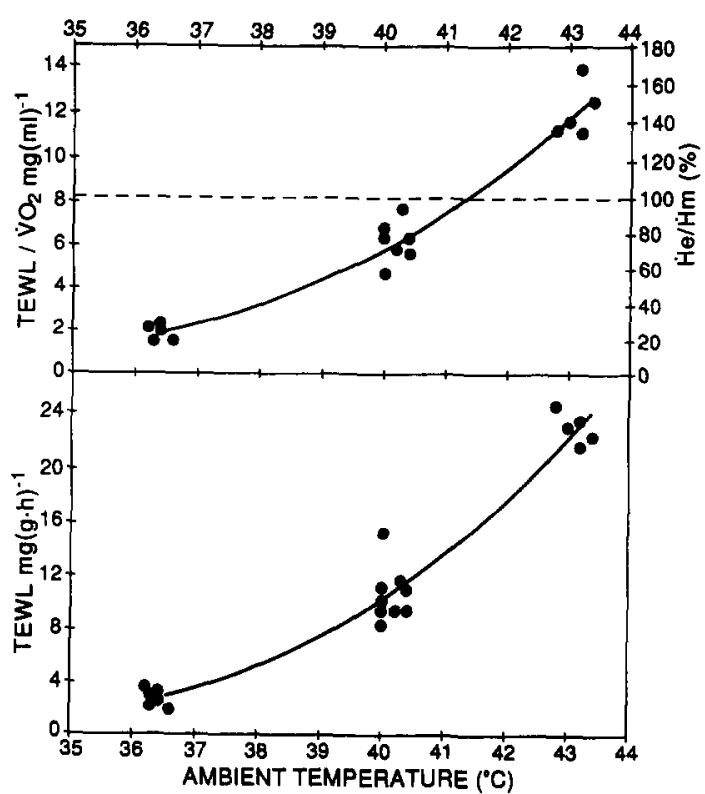

Fig. 5. Pulmocutaneous evaporative water loss (TEWL) of hatchling brown noddies at various ambient temperatures. The solid line is the least squares regression line (see equation (13) in Table 1). The ratios of pulmocutaneous water loss (TEWL) to oxygen consumption $\left(\mathrm{VO}_{2}\right)$ and of evaporative heat loss $\left(H_{e}\right)$ to metabolic heat production $\left(\dot{H}_{\mathrm{m}}\right)$ in the hatchlings at various ambient temperatures are illustrated in the upper panel. Heat production and evaporative heat loss were estimated from $\mathrm{VO}_{2}$ and TEWL, respectively, by use of the following relationships: $1 \mathrm{ml} \mathrm{O}$ consumed $=20.08 \mathrm{~J}$ and $1 \mathrm{mg} \mathrm{H} \mathrm{H}_{2} \mathrm{O}$ evaporated $=2.43 \mathrm{~J}$. The solid line is the least squares regression line fitted to the data (see equation (14) in Table 1). The horizontal line (---) marks equivalence between $H_{\mathrm{m}}$ and $H_{\mathrm{e}}$.

rested quietly and often slept in the metabolism chamber at a $T_{\mathrm{a}}$ of $36^{\circ} \mathrm{C}$. However, they became restless and panted continuously at $42^{\circ} \mathrm{C}$ and higher. We measured TEWL of 21 hatchlings in conjunction with the determinations of $\dot{V} \mathrm{O}_{2}$ at $T_{\mathrm{a}}$ between 36 and $43^{\circ} \mathrm{C}$ (Fig. 5; equation (13), Table 2). It increased approx. 8-fold over this temperature range, averaging $2.91 \pm 0.59 \quad(N=7), \quad 10.85 \pm 2.03 \quad(N=9)$ and $23.24 \pm 1.11(N=5) \mathrm{mg} \mathrm{H}_{2} \mathrm{O}(\mathrm{g} \mathrm{h})^{-1}$ near 36,40 and $43^{\circ} \mathrm{C}$, respectively. The respective ratios of TEWL to $\dot{V} \mathrm{O}_{2}$ at these $T_{\mathrm{a}}$ (Fig. 5; equation (14), Table 2) averaged $1.93,6.11$ and $12.11 \mathrm{mg} \mathrm{H}_{2} \mathrm{O} / \mathrm{ml} \mathrm{O}_{2}$. Parity between evaporative cooling and heat production is associated with a value of approx. $8.3 \mathrm{mg} / \mathrm{ml}$.

\section{DISCUSSION}

\section{Metabolic trends during late incubation}

Gas exchange between the environment and the intact avian egg occurs by diffusion through the egg shell (Romanoff and Romanoff, 1949; Wangensteen and Rahn 1970/71). Our finding of a significantly higher $\dot{V} \mathrm{O}_{2}$ in internally pipped than in externally pipped eggs $(P<0.05)$ supports Kutchai and Steen's (1971) conclusion that the inner shell membrane provides the greatest resistance to $\mathrm{O}_{2}$ diffusion. The further significant $(P<0.05)$ rise in $\dot{V} \mathrm{O}_{2}$ with the establishment of a pip-hole also presumably reflects an improved access to oxygen. Our observations on $\dot{V} \mathrm{O}_{2}$ during these late stages of incubation are consistent with Pettit and Whittow's (1983) results. Their measurements of brown noddy eggs extended over the entire incubation period, with the largest increase in $\dot{V} \mathrm{O}_{2}$ occurring between external pipping and hatching. Again, this increase seemed to be primarily a product of the breakdown in the barrier to gaseous diffusion presented by the shell and the shell membranes. However, the rise in embryonic mass that occurred over these stages (Table 1) probably contributed as well. It is of interest that the mean for the metabolic rates of brown noddies in pip-holed eggs at $38^{\circ} \mathrm{C}$ does not differ significantly from the value for thermoneutral metabolism observed for hatchlings $\left(1.62 \pm 0.16\right.$ and $1.56 \pm 0.18 \mathrm{ml} \mathrm{O}_{2}[\mathrm{~g} \mathrm{~h}]^{-1}$ for the former and latter, respectively).

Embryonic brown noddies in the last days before hatching produced sufficient heat to maintain $T_{\mathrm{b}}$ slightly above $T_{\mathrm{a}}$ at the end of our metabolic tests (Fig. 1). Such a differential between $T_{\mathrm{b}}$ and $T_{\mathrm{a}}$ during the latter stages of development has been noted previously for avian embryos (Romanoff, 1941; Tazawa and Rahn, 1987). It tends to increase in brown noddies over the period from just before external pipping through internal pipping. The lack of a further increase in this differential with the creation of a pip hole is of interest because of the higher $\dot{V} \mathrm{O}_{2}$ evident at the latter stage (Fig. 1). Perhaps increased evaporative and convective heat loss through the pip hole offsets the increased heat production.

Domestic fowl (Gallus gallus) are precocial birds and their embryos have some limited capacity for resisting cooling during the latter stages of incubation (Freeman, 1964; Tazawa et al., 1987). We wondered whether the fact that brown noddy embryos can remain slightly warmer than their surroundings in the days just before hatching (Fig. 1) might indicate a similar situation. However, we did not find any active cold defence at the end of 90-min tests. This appears primarily linked with the absence of any detectable regulatory thermogenesis at moderate and cool temperatures, a circumstance indicated by the direct relation between $\dot{V} \mathrm{O}_{2}$ and $T_{\mathrm{a}}$ (Fig. 1). Such a relation contrasts with Bennett and Dawson's (1979) finding that $\dot{V} \mathrm{O}_{2}$ of week-old eggs of the semi-precocial Heermann's gull (Larus heermanni) were similar at $T_{\mathrm{a}}$ of 20 and $30^{\circ} \mathrm{C}$. These eggs were in the first trimester of incubation and thus the embryos were relatively immature. This leads us to believe that the stability of their metabolism over the $10^{\circ} \mathrm{C}$ interval reflects low thermal sensitivity rather than a nascent capacity for regulatory thermogenesis. We should note that $\dot{V} \mathrm{O}_{2}$ of advanced brown noddy embryos is strongly correlated with $T_{b}$, as well as with $T_{\mathrm{a}}$, and our results for the four egg stages we studied indicate $Q_{10}$ 's ranging from approx. 1.7 to 2.3 (Table 1). Thus, they appear, in Tazawa et al.'s (1987) phrase, to be "Arrhenius limited", i.e. they behave like ectotherms with respect to the thermal dependence of their metabolic rate. Our results indicating a lack of regulatory thermogenesis in late noddy embryos are consistent with those Matsunaga et al. (1989). In their study, brown noddy eggs were slowly cooled until they reached a "quasi-equilibrium state", defined as a change of $<0.1^{\circ} \mathrm{C} / \mathrm{h}$. No homeothermic 


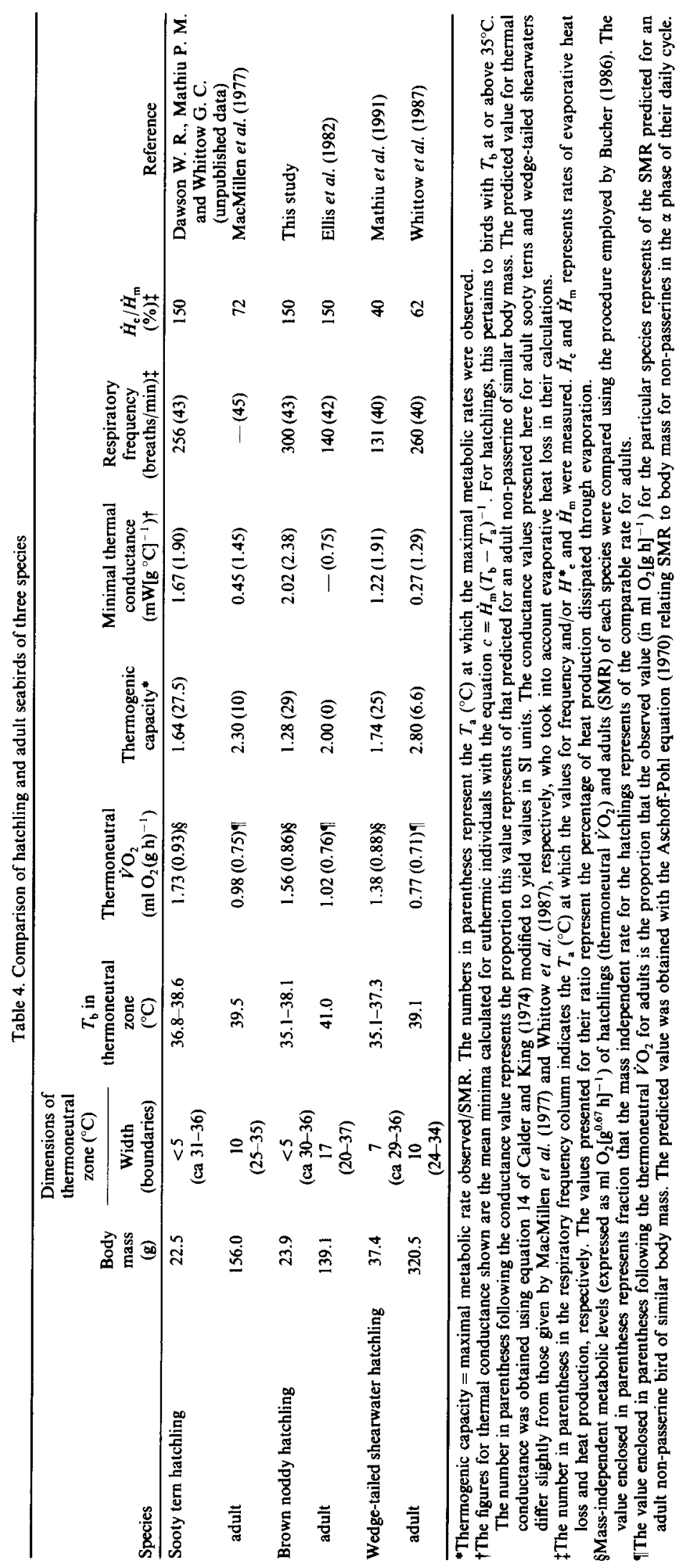


responses were detected during this cooling, even in late embryos.

\section{Thermoregulatory capacities of hatchlings}

On the basis of maturity at hatching, brown noddies are regarded as semi-precocial birds (Pettit et al., 1984). They resemble other semi-precocial seabirds (Dawson, 1984; Bech et al., 1984, 1987; Brown and Prys-Jones, 1988; Mathiu et al., 1992) in possessing some capacity for regulatory thermogenesis (Fig. 2) and effective evaporative cooling (Fig. 5) shortly after emergence from the egg. Moreover, when comparisons are made on a basis serving to reduce substantially or eliminate the effects of differences in body mass (see Bucher (1986) for discussion of mass-independent metabolic rates), their thermoneutral metabolic level represents $93 \%$ of the standard metabolic rate (SMR) of adult brown noddies (Table 4). The contrasting thermal responses of advanced embryos and hatchlings mark hatching as a major gateway for the development of homeothermy in the brown noddy. In the days immediately preceding hatching, the chorioallantoic circulation is terminated, reducing thermolysis. Hatching itself leads to removal of the physical constraints imposed by the shell, which should improve opportunities for movement, increased ventilation and, perhaps, intensified shivering. Finally, once the chick has emerged from the egg, drying allows the maximization of the insulation provided by the down. Beyond these changes, maturation processes leading to the development of effective thermosensors, controllers and effectors probably are involved as well. We lack information on such processes in the brown noddy. However, work on other species provides some indication of things to look for. For example, the appearance of endothermy in the altricial nestlings of the bank swallow (Riparia riparia) coincides with an increase in $\mathrm{Ca}-, \mathrm{Mg}$ activated myofibrillar ATPase activity in their pectoral muscles (Marsh and Wickler, 1982). Additionally, a good correlation exists between the maturation of the thyroid gland and establishment of higher circulating levels of thyroid hormones, and the onset of endothermic responses to cooling (McNabb, 1987). This establishment is rather sudden in the precocial Japanese quail (Coturnix japonica), occurring during the perinatal period, and the appearance of thermoregulatory responses to cold is similarly abrupt. Circulating levels of thyroid hormones rise more slowly in the young of the ring dove (Streptopelia risoria), reaching a plateau at about 6-8 days after hatching. The coincident increase in endothermic capacity is likewise gradual (McNabb, 1987).

Qualitatively, hatchling brown noddies resemble their adults in possessing capacities for regulatory thermogenesis (Fig. 2), insulative adjustments (see preceding comments on $c$ ), and evaporative cooling (Fig. 5). However, they differ from these older birds in some important respects. The $T_{\mathrm{b}}$ of these chicks at a neutral $T_{\mathrm{a}}\left(36^{\circ} \mathrm{C}\right)$ averaged $38.1^{\circ} \mathrm{C}$, a value nearly $3^{\circ} \mathrm{C}$ below the $T_{\mathrm{b}}$ of the adults (Ellis et al., 1982). These young terns also have far more limited capacities for cold induced thermogenesis than adults, reaching a summit at $29^{\circ} \mathrm{C}$ that is only $1.28 \times$ thermoneutral metabolism. This indicates a much lower capacity for metabolic expansibility in the cold than that of adult brown noddies (Table 4). The inability of the hatchlings to offset the additional heat loss occurring at $T_{\mathrm{a}}$ below $29^{\circ} \mathrm{C}$ by increased thermogenesis resulted in progressive hypothermia and reduced metabolism, producing the relationships illustrated in Fig. 2. The capacities of hatchlings for maintaining heat balance by insulative adjustments also appears very limited, judging by the high, relative to adult standards, values for thermal conductance evident in Table 4. This limitation is reflected in the narrow zone of thermal neutrality evident in Fig. 2.

Greater similarity of hatchlings and adults exists in the area of heat defence. Both show vigorous panting responses (Ellis et al., 1982). However, the maximal respiratory frequency noted in the younger birds was nearly twice that in the older ones (Table 4), in keeping with the size differential between them. Both responded to higher $T_{\mathrm{a}}$ with a controlled hyperthermia and both could dissipate more heat evaporatively than they produced under these conditions, allowing them to remain cooler than their surroundings at $T_{\mathrm{a}}$ up to at least $43^{\circ} \mathrm{C}$. Upper lethal temperatures for birds are only a few degrees above normal $T_{b}$ (Dawson and Hudson, 1970) and the well developed capacities for heat defence evident in hatchlings could be important for protecting them from overheating under warm conditions with intense insolation, when they are not being shaded by a parent.

Interspecific comparisons of metabolic level and capacities for cold-induced thermogenesis in precocial and semi-precocial birds

The previously noted fact that mass-independent metabolic rates (expressed as $\mathrm{ml} \mathrm{O}_{2}\left[\mathrm{~g}^{0.67} \mathrm{~h}\right]^{-1}$ ) of brown noddy hatchlings at thermoneutrality represent $93 \%$ of the comparable value of SMR for adults (Table 4) suggests that post-hatching development in this species involves no major changes in metabolic intensity beyond those associated with increasing body mass. This is also the case for the sooty tern (Sterna fuscata) and the wedge-tailed shearwater (Puffinus pacificus), two other tropical seabirds we have studied (Table 4). Mass-independent metabolic values for the hatchlings of these other species at thermoneutral $T_{\mathrm{a}}$ represent 86 and $88 \%$, respectively, of the comparable expressions of SMR for conspecific adults. The percentage obtained for the wedge-tailed shearwater is substantially higher than that of $55 \%$ for this species and the $40-68 \%$ for several other procellariiforms calculated by Bucher (1986). It is closer to the figure of $75 \%$ derived from a comparison of metabolic values for hatchling and adult Manx shearwaters, Puffinus puffinus (Bech et al., 1982). Our figure for the wedge-tailed shearwater also approximates that of $82 \%$ Bucher (1986) gives for the Laysan albatross (Diomedea immutabilis), another representative of the order Procellariiformes. The percentages we obtained for the ratios of hatchling to adult levels of massindependent metabolism in brown noddies and sooty terns also substantially exceed those calculated by Bucher (1986) for these birds and black noddies, Anous tenuirostris $(86-93 \%$ vs $59-64 \%)$. These discrepancies probably involve differences among studies in experimental design and measurement procedures and in the precise age of the hatchlings, problems also recognized by Bucher (1986). The use 
of mass-independent metabolic values facilitates interspecific comparisons of metabolic levels between embryos or chicks and adults, but caution appears in order in interpreting the results until the "noise" produced by these discrepancies is substantially reduced.

As noted above, the maximal rate of cold-induced thermogenesis by hatchling brown noddies only exceeds their thermoneutral metabolism by $1.28 \times$. The comparable factors for hatchling sooty terns and wedge-tailed shearwaters are 1.64 and 1.74, respectively (Table 4). Adults of the three species do only slightly better $(2-2.8 \times$, Table 4$)$. These factors for hatchlings and adults are well below the values relating summit metabolism to SMR in adult passerines, which commonly range from approx. $5 \times$ to greater than $6 \times$ (Dawson and Marsh, 1989). The factors for the hatchlings match or fall below those of 1.5-3.4 obtained for the semiprecocial hatchlings of various gulls (Kespaik and Davydov, 1966; Dawson et al., 1972, 1976; Dunn, 1976; Dawson and Bennett, $1980,1981)$. Thermogenic capacity of all these semiprecocial hatchlings is surpassed by that of newly hatched ducklings, which are precocial. The latter can augment heat production in the cold by factors of 2.4-5.2 $\times$ thermoneutral rates (Koskimies and Lahti, 1964). However, the mass-independent metabolic rates of these ducklings match or fall slightly below those of the hatchling gulls and terns. This circumstance suggests that general metabolic level and thermogenic capacity of developing precocial and semi-precocial birds are not tightly coupled.

Acknowledgements-This work was carried out at the University of Hawail while P. M. Mathiu held a NORAD Fellowship and was on study leave from the University of Nairobi. We gratefully acknowledge the support provided by grants from the National Geographic Society and the Frank M. Chapman Fund. We also thank the State of Hawaii Division of Forestry and Wildlife (Department of Land and Natural Resources) and the U.S. Fish and Wildlife Service for granting permits.

\section{REFERENCES}

Aschoff J. and Pohl H. (1970) Rhythmic variations in energy metabolism. Fedn Proc. Fedn Am. Socs exp. Biol. 29, 1541-1552.

Bech C., Aarvik F. J. and Vongraven D. (1987) Temperature regulation in hatchling puffins (Fratercula arctica). J. Orn. Lpz. 128, 163-170.

Bech C., Brent R., Pedersen P. F., Rasmussen J. G. and Johansen K. (1982) Temperature regulation in chicks of the Manx shearwater Puffinus puffinus. Ornis scand. 13, 206-210.

Bech C., Martini S., Brent R. and Rassmussen J. (1984) Thermoregulation in newly-hatched black-legged kittiwakes. Condor 86, 339-341.

Bennett A. F. and Dawson W. R. (1979) Physiological responses of embryonic Heermann's gulls to temperature. Physiol. Zool. 52, 413-421.

Brown C. R. and Prys-Jones R. P. (1988) Development of homeothermy in chicks of sub-antarctic burrowing petrels. S. Afr. Tystskr. Dirk. 23, 288-294.

Bucher T. L. (1986) Ratios of hatchling and adult massindependent metabolism: a physiological index to the altricial-precocial continuum. Resp. Physiol. 65, 69-83.

Calder W. A. and King J. R. (1974) Thermal and caloric relations of birds. In Avian Biology (Edited by Farner
D. S. and King J. R.), Vol. IV, pp. 259-414. Academic Press, New York.

Dawson W. R. (1984) Metabolic responses of embryonic seabirds to temperature. In Seabird Energetics (Edited by Whittow G. C. and Rahn H.), pp. 139-157. Plenum, New York.

Dawson W. R. and Bennett A. F. (1980) Metabolism and thermoregulation in hatchling western gulls (Larus occidentalis livens). Condor 82, 103-105.

Dawson W. R. and Bennett A. F. (1981) Field and laboratory studies of the thermal relations of hatchling western gulls. Physiol. Zool. 54, 155-164.

Dawson W. R. and Hudson J. W. (1970) Birds. In Comparative Physiology of Temperature Regulation (Edited by Whittow G. C.), Vol. I, pp. 223-310. Academic Press, New York.

Dawson W. R. and Marsh R. L. (1989) Metabolic acclimatization to cold and season in birds. In Physiology of Cold Adaptation in Birds (Edited by Bech C. and Reinertsen R. E.), pp. 83-94. Plenum, New York.

Dawson W. R., Bennett A. F. and Hudson J. W. (1976) Metabolism and thermoregulation in hatchling ring-billed gulls. Condor 78, 49-60.

Dawson W. R., Hudson J. W. and Hill R. W. (1972) Temperature regulation in newly hatched laughing gulls (Larus atricilla). Condor 74, 177-184.

Dunn E. H. (1976) The development of endothermy and existence energy expenditure in herring gull chicks. Condor 78, 493-498.

Ellis H. I., Maskrey M., Pettit T. N. and Whittow G. C. (1982) Temperature regulation in Hawaiian brown noddies (Anous stolidus pileatus). Physiologist 25, 279 (abstract).

Freeman B. M. (1964) The emergence of homeothermic metabolic response in the fowl (Gallus domesticus). Comp. Biochem. Physiol. 13, 412-422.

Hill R. W. (1972) Determination of oxygen consumption by use of the paramagnetic oxygen analyzer. J. appl. Physiol. 33, 261-263.

Kespaik J. and Davydov A. (1966) Factors determining the cold-hardiness of the Larus ridibundus $\mathrm{L}$. on the first day after hatching. Toimetised Eesti NSV Teaduste Akadeemia $X V$, Biol. Seeria Nr. 4, 485-491 (in Russian with English summary).

Koskimies J. and Lahti L. (1964) Cold-hardiness of the newly hatched young in relation to ecology and distribution in ten species of European ducks. Auk 81, 281-307.

Kutchai H. and Steen J. B. (1971) Permeability of the shell and shell membranes of hens' eggs during development. Resp. Physiol. 11, 265-278.

MacMillen R. E., Whittow G. C., Christopher E. A. and Ebisu R. E. (1977) Oxygen consumption, evaporative water loss, and body temperature in the sooty tern. Auk 94, 72-79.

Marsh R. L. and Wickler S. J. (1982) The role of muscle development in the transition to endothermy in nestling bank swallows (Riparia riparia). J. comp. Physiol. B 149, 99-105.

Mathiu P. M., Dawson W. R. and Whittow G. C. (1992) Hatching and the establishment of temperature regulation in the wedge-tailed shearwater (Puffinus pacificus). Physiol. Zool. In press.

Matsunaga C., Mathiu P. M., Whittow G. C. and Tazawa $\mathbf{H}$. (1989) Oxygen uptake of brown noddy (Anous stolidus) embryos in a quasiequilibrium state of lowered ambient temperatures. Comp. Biochem. Physiol. 93A, 707-710.

McNabb F. M. A. (1987) Comparative thyroid development in precocial Japanese quail and altricial ring doves. J. exp. Zool. Suppl. 1, 281-290.

Pettit T. N. and Whittow G. C. (1983) Embryonic respiration and growth in two species of noddy terns. Physiol. Zool. 56, 455-464. 
Pettit T. N., Whittow G. C. and Grant G. S. (1984) Caloric content and energetic budget of tropical seabird eggs. In Seabird Energetics (Edited by Whittow G. C. and Rahn H.), pp. 113-137. Plenum Press, New York.

Romanoff A. L. (1941) Development of homeothermy in birds. Science 94, 218-219.

Romanoff A. L. and Romanoff A. T. (1949) The Avian Egg, p. xiii +918 . Wiley, New York.

Tazawa H. and Rahn H. (1987) Temperature and metabolism of chick embryos after prolonged cooling. $J$. exp. Zool. Suppl. 1, 105-110.

Tazawa H., Suzuki Y., Turner J. S. and Paganelli C. V. (1987) Metabolic compensation for gradual cooling in developing chick embryos. Comp. Biochem. Physiol. 87A, $125-129$.

Walsberg G. E. and King J. R. (1978) The relationship of the external surface area of birds to skin surface area and body mass. J. exp. Biol. 76, 185-189.

Wangensteen O. D. and Rahn H. (1970/71) Respiratory gas exchange by the avian embryo. Resp. Physiol. 11, $31-45$.

Whittow G. C., Pettit T. N., Ackerman R. A. and Paganelli C. V. (1987) Temperature regulation in a burrow nesting tropical seabird, the wedge-tailed shearwater (Puffinus pacificus). J. comp. Physiol. B 157, 607-614. 